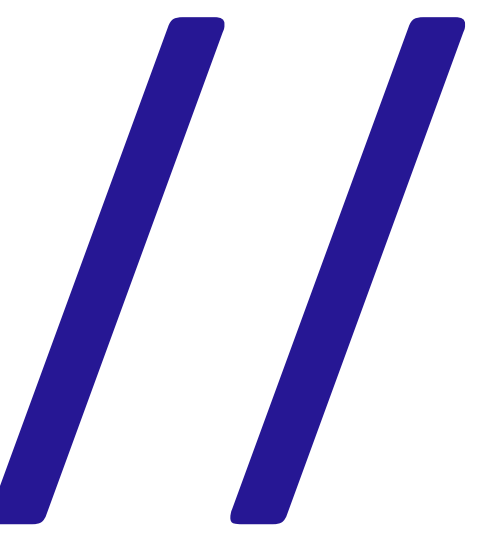

\title{
Relações de classe em documentários brasileiros
} contemporâneos Class relations in contemporary Brazilian documentaries

Mariana Souto ${ }^{1}$

\footnotetext{
Professora na Faculdade de Comunicação da Universidade de Brasília (UnB). Doutora em Comunicação pela Universidade Federal de Minas Gerais (UFMG) com bolsa da Coordenação de Aperfeiçoamento de Pessoal de Nível Superior (Capes). Pós-doutorado na Escola de Comunicações e Artes da Universidade de São Paulo (ECA-USP) com bolsa Fundação de Amparo à Pesquisa do Estado de São Paulo (Fapesp). E-mail:mariana.souto@unb.br
} 
Resumo: Este artigo propõe investigar como as relações de classe extra fílmicas informam e modulam obras documentais, além de promover uma discussão atualizada sobre a noção de "outro de classe" nas situações em que patrões filmam seus empregados domésticos. São analisados filmes do contexto brasileiro contemporâneo como Santiago (João Moreira Salles, 2007), Babás (Consuelo Lins, 2010) e Doméstica (Gabriel Mascaro, 2012).

Palavras-chave: classes sociais; documentário; emprego doméstico; cinema brasileiro contemporâneo.

Abstract: This paper investigates the way extra-filmic class relations inform and modulate documentaries, as well as discusses the notion of "outro de classe" in situations where bosses film their domestic servants. We analyze films of the contemporary Brazilian context such as Santiago (João Moreira Salles, 2007), Babás (Consuelo Lins, 2010) e Doméstica (Gabriel Mascaro, 2012).

Keywords: social classes; documentary; domestic employees; contemporary Brazilian cinema. 
No cinema documentário, além dos temas e sujeitos tornados imagem, imprime-se também as marcas da relação entre documentaristas e documentados, relação esta permeada por ingredientes de poder. Muitas vezes, entre essas duas pontas da câmera se interpõe um importante elemento: a diferença de classe social. Esse modulador das relações pode ser encontrado em diversos cinemas desde A saída dos operários da fábrica (Louis Lumière, 1895), feito pelos donos da indústria Lumière registrando seus próprios empregados, o cinema se funda nessa relação em que quem detém a câmera geralmente também detém maior poder econômico e social. Isso se faz especialmente relevante no Brasil, país de acentuada desigualdade de renda e com diversos conflitos, ora agudos ora velados, entre as diferentes classes. Jean-Louis Comolli (2010) discorre sobre essa relação no âmbito do documentário apontando que, para entender as coordenadas de um plano, é preciso levar em conta não apenas suas condições espaço-temporais e político-históricas, mas o que acontece entre quem filma e quem é filmado. "Eu diria que, se algo é documentado, é essa relação” (COMOLLI, 2010, p. 339).

Este artigo pretende questionar o que acontece quando a essa relação cinematográfica de poder se justapõe uma relação social de poder ou, inversamente, o que acontece quando a uma relação social de poder preexistente se soma uma relação cinematográfica de poder.

Essas questões são despertadas quando da aproximação dos filmes Babás (2010), curta-metragem de Consuelo Lins, sobre profissionais que cuidaram da cineasta, de seus filhos e amigos; Santiago (2007), longa de João Moreira Salles, recebe o nome do ex-mordomo da família do diretor; e Doméstica (Gabriel Mascaro, 2012), a respeito de empregadas domésticas filmadas pelos filhos adolescentes de seus empregadores. Os dois primeiros compartilham características como a forte inflexão subjetiva, o caráter ensaístico, a narração confessional em primeira pessoa e a coincidência entre patrão e cineasta e serão analisados em maior profundidade, enquanto o terceiro virá somar com participações mais pontuais. Apesar de muitas diferenças, os três filmes trazem o olhar dos patrões para os trabalhadores domésticos. Busca-se investigar em que medida relações de classe extrafílmicas informam e modulam tais obras documentais, além de promover uma discussão atualizada sobre a noção de "outro de classe" (BERNARDET, 2003). 


\section{Patrões e empregados, filmantes e filmados}

As relações entre patrões e empregados domésticos parecem ter se constituído como um dos principais redutos das relações de classe no cinema brasileiro hoje ${ }^{2}$. Se os documentários atuais tratam em menor proporção de operários de chão de fábrica, sindicalistas ou grevistas em relação aos burgueses capitalistas, ou de imigrantes nordestinos, sertanejos miseráveis e analfabetos em relação a fazendeiros ou empregadores da construção civil em cidades grandes - como em Viramundo (1965), Maioria absoluta (1964), ABC da greve (1979-90), Linha de montagem (1982), Braços cruzados, máquinas paradas (1979), entre outros -, as profissões domésticas têm sido especialmente presentes. Babás, Santiago e Doméstica abordam funcionários que trabalham dentro dos apartamentos, casas ou prédios de patrões de classes médias e altas, configurando relações que embaçam as fronteiras entre espaço público e privado, vida profissional e pessoal, formalidade e intimidade. Se, como aponta Carla Barros, “a intimidade age, de certo modo, 'diluindo' a aridez das relações de poder" (BARROS, 2007, p. 123), de outro é capaz de embaralhar expectativas, deixando os sujeitos em lugares instáveis, confusos a respeito de direitos e deveres "ela é quase da família", diz a velha frase. Ao mesmo tempo em que amacia ordens, a proximidade afetiva mascara hierarquias e disfarça abusos de autoridade.

Babás e Santiago partem de imagens retiradas de arquivos, tanto pessoais quanto alheias (sejam fotografias de crianças e suas amas de leite, filmagens caseiras ou o material bruto de um documentário filmado há treze anos) para tecer um ensaio, uma investigação errante, povoada de incertezas e derivas (BRASIL, 2010). Nos dois filmes, os cineastas espreitam, investigam e analisam, por meio das vivências pessoais, relações de poder que os extrapolam.

Observamos assim, no trato de histórias íntimas, a possibilidade de mobilização dos contrastes, distâncias e proximidades entre, de um lado, elites e camadas médias e, do outro, as classes baixas. Os filmes, que assumem uma visão em plongée da pirâmide social brasileira, trazem a marca da má consciência de classe. Nesse sentido, talvez sejam obras mobilizadas por um desejo de indenizar uma dívida histórica. Não podemos deixar de notar que eles figuram como certa novidade no cinema brasileiro não exatamente por se calcarem nas perspectivas da elite, mas por sua explicitação - a desigualdade é confessa e a dívida, dramatizada.

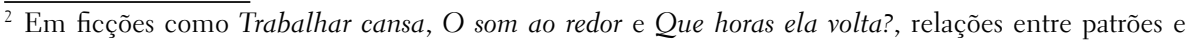
empregados domésticos também são problematizadas, em relações de alteridade que figuram um intenso sentimento de desconforto, medo ou paranoia - a ameaça do outro de classe dentro de casa (SOUTO, 2019).
} 
Tanto Consuelo Lins quanto João Salles buscam compensar uma invisibilidade prévia produzindo retratos de seus entrevistados, dedicando-lhes uma escuta, ao mesmo tempo em que revisitam seus próprios enganos e limites. Na narração, Salles expressa um mea culpa ao dizer que, no momento da feitura das imagens, tratou Santiago de maneira autoritária, não lhe deu atenção quando este quis compartilhar um segredo. Sobre uma antiga babá de seu filho, Lins discorre: "Eu não podia imaginar um trabalho que me obrigasse a ficar seis dias longe do meu filho. Preferi não pensar na situação dela nessa época".

Vemos que, no trabalho com imagens de arquivo, a retomada evoca o momento da tomada (LINDEPERG; COMOLLI, 2010), tornando nítida uma distância entre os dois tempos que aqui se pauta por uma espécie de evolução (EDUARDO, 2007). Antes não escutei, agora ouço. Antes neguei, agora vejo. Ainda assim, certas tentativas de reparo carregam uma ambiguidade: até que ponto as posições de patrão/empregado se aproximam ou se distanciam das de documentarista/ documentado? Em que medida a relação de trabalho e a pertença a classes opostas se imprimem nos filmes? Ainda que os empregados sejam os protagonistas e até mesmo batizem as obras, qual é sua verdadeira possibilidade de expressão?

Nesse sentido, interessa-nos investigar, em Babás e Santiago, as relações entre os sujeitos filmantes e filmados sobretudo por meio da observação da mise-en-scène, o momento crucial de interação entre as partes mediada pela câmera e por meio da montagem. Essa última tem um papel decisivo nos filmes, que se valem de imagens de outras épocas, articulando passado (seja o pessoal ou o nacional) e presente e ainda adicionando a camada do comentário em voz over. Buscamos considerar, ainda, as singularidades da forma ensaística/reflexiva no cinema documental.

Babás e Santiago, na condição de documentários reflexivos, que pensam sua própria forma e expõem traços de sua feitura, acabam por convocar para a análise elementos do fora de quadro ${ }^{3}$, daquilo que participa do processo de produção do filme, mas que geralmente não é visível e nem se faz presente na cena. Não pensamos o fora de quadro somente no sentido mais prático dos bastidores, como tudo aquilo que se coloca no set e acaba por constranger a filmagem, mas também, de modo ampliado, como os atravessamentos, na imagem, de macrodimensões como as relações de poder extrafílmicas, o modo capitalista de produção, as relações materiais que guiam todo o processo.

\footnotetext{
$\overline{3}$ Esse conceito é diferenciado do de "fora de campo", que embora não seja visto, prolonga o campo, estando integrado ao imaginário do filme, ainda imerso em sua ilusão.
} 


\section{Babás}

Ao longo de Babás, Consuelo Lins observa, descreve, especula e constata a invisibilidade histórica das babás no contexto brasileiro, analisando algumas de suas poucas aparições. Para essa análise, transita entre dados de macro e microdimensões, investigando tanto arquivos nacionais como sua própria vida e a de seus próximos. A cineasta passa de suas experiências pessoais - a exemplo de sua infância, quando era cuidada por babás, como a atual patroa cujo filho é assistido por elas - a entrevistas com babás de amigos, observação das profissionais em atividade, análise de anúncios de jornais, fotos e filmes de arquivo espalhados ao longo do século XX. Observações e entrevistas com uma variedade de mulheres no presente são vinculadas ao ofício da ama de leite no período colonial, fazendo emergir dessa conexão a perenidade das estruturas sociais no Brasil, com sua imensa desigualdade e os abusos no trato de um segmento social sobre outro.

Uma voz, em tom doce, reflexivo e confessional, organiza e costura esse material extremamente heterogêneo. É interessante notar que, tanto em Babás como em Santiago, a narração fala em primeira pessoa, mas não é do próprio diretor: Babás é narrado por Flávia Castro, cineasta amiga da diretora, ao passo que a voz emprestada ao filme de João Salles é a de Fernando, seu irmão. Trata-se de uma “primeira pessoa terceirizada”, conforme apontamento de Ilana Feldman (2013) a respeito de Santiago, mas que se aplica também para Babás.

Ainda que variado, o material utilizado no filme caminha no mesmo sentido de atestar a invisibilidade das babás na produção de imagens familiares. O documentário parece ter sua existência motivada pelo desejo de compensar essa falha histórica, desejo esse que parece impulsionado por um sentimento de culpa e pela tentativa de ressarcimento de um prejuízo infringido.

Consuelo Lins descreve relações de maneira crítica, interpreta imagens com perspicácia. Com a força de todo o seu método, confirma uma injustiça; nesse sentido, envolve-se na tentativa de minimizá-la. Em sua reflexão, no entanto, pouco notamos uma busca pelos motivos da dita invisibilidade. Sabemos apenas tratar-se de um fenômeno de raízes antigas, históricas, que se repete até a contemporaneidade, embora com atualizações e transformações.

Diante dessa complexa relação, Lins mais lamenta do que interroga em profundidade - reveladas as anomalias de um status quo, agora podemos fazer algumas compensações. Há momentos em que a diretora expõe, de maneira franca, suas limitações, suas recusas, como no relato sobre Denise, que ficava seis dias sem ver a filha para cuidar do filho da diretora. 
Constatado o desnível entre o tratamento que as babás deveriam receber e aquele que de fato recebem, Consuelo Lins parece mobilizada em produzir, ela mesma, os retratos (em movimento) que essas mulheres possivelmente nunca tiveram. Em determinada sequência (Figura 1), a diretora filma cinco babás que trabalharam com ela ao longo dos anos. Elas são colocadas lado a lado, viradas de frente para a câmera, em enquadramento que as toma de corpo inteiro, enquanto narra-se em off: "Vera Lúcia, Denise, Vera, Creuza, Andrea. Não conseguiria dizer aqui o quanto essas moças me ajudaram em muitos momentos da minha vida”. Após essa frase, há um corte. As babás, que estavam em roupas próprias, coloridas e diferentes entre si, agora vestem branco, ocupando ainda a mesma disposição no espaço. A voz continua: "Com meu filho e meus sobrinhos, com a casa, com a comida, com as compras, com as idas e vindas das crianças". Essa passagem de certa forma mimetiza o processo de transformação de moças, que têm nomes próprios, subjetividades, individualidades e preferências pessoais, em babás uniformizadas (não apenas no vestuário), que têm funções e responsabilidades quando ingressam nas casas dos patrões.

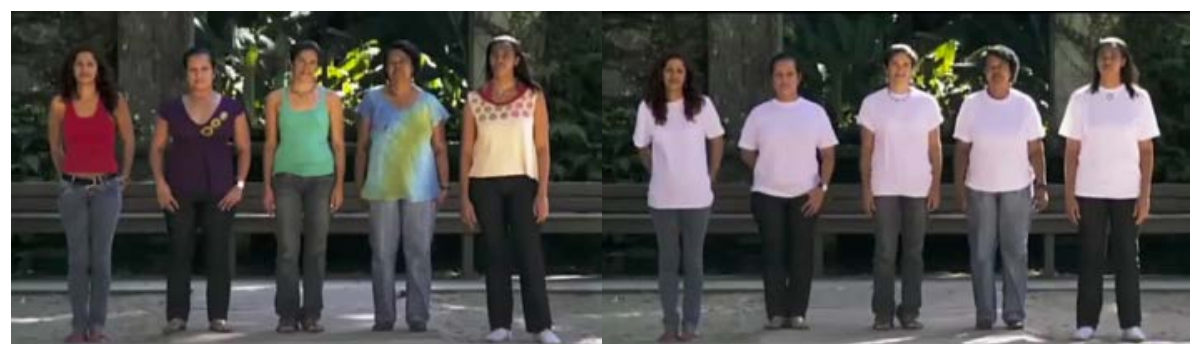

Figura 1: Fotogramas de Babás.

Por mais que Consuelo Lins tenha tentado oferecer atenção e gratidão às moças que foram excluídas das imagens da família em anos anteriores, buscando assim restabelecer um equilíbrio nas desiguais relações de poder, seus retratos no presente filme talvez prolonguem uma mise-en-scène pautada pela relação de obediência, a designação de um corpo a um determinado espaço, um pedido de postura, de uma vestimenta, de um olhar. A posição de patroa aqui parece se confundir com a de diretora. Em dado momento, a narração profere: "Não me senti à vontade para entrevistar quem ainda trabalha comigo. Achei que essas conversas poderiam ser comprometidas pela situação patroa-empregada. Mas conversei com as babás dos amigos e conhecidos". É certo que as entrevistas com os próprios contratados poderiam ser comprometidas pelos papéis sociais, mas a conversa com as babás de amigos não está isenta de atravessamentos semelhantes. A diretora não 
é patroa apenas de sua babá, mas porta uma espécie de condição social de patroa, carregando consigo as marcas de uma classe social em vantagem sobre outra.

Esse processo de "branqueamento" das roupas, de homogeneização e “asseptização" das funcionárias muitas vezes é acompanhado de um apagamento dos traços de personalidade, das diferenças, da esfera das relações pessoais exteriores ao ambiente de trabalho, sobretudo para as que dormem no serviço. É como se essas mulheres existissem apenas em função do emprego, tendo usurpadas algumas esferas de sua vida, como a possibilidade de uma relação amorosa ou o desenvolvimento de uma família própria. Nos anúncios, são procuradas babás "sem compromisso"; algumas relatam os protestos das patroas quando se inteiram dos seus planos de casamento.

Tais escolhas, limites e dificuldades são, a bem da verdade, sintomáticos de um filme mergulhado na cultura brasileira. Se, de um lado, o envolvimento direto no assunto do documentário traz uma riqueza de reflexões, uma autêntica visão de dentro, por outro, pode também atuar como dificultador na problematização de certas questões. Embora seja corajoso o fato de que a culpa e a má consciência se tornem manifestas, elas, de algum modo, acabam por comprometer um enfrentamento de causas e de incômodos. Sem uma reflexão mais interrogativa, mais propensa a deslocar sujeitos e saberes de seus lugares, alguns traços culturais, de tão arraigados, acabam se repetindo talvez de maneira inconsciente, mantendo hierarquias e distâncias quando o propósito era justamente rompê-las.

\section{Santiago}

Em 1992, João Moreira Salles filmou Santiago, o mordomo que trabalhou muitos anos na mansão de sua família no Rio de Janeiro. Excêntrico, com uma memória extraordinária e um gosto pela aristocracia, Santiago era um senhor argentino, aposentado, que tinha cerca de 80 anos de idade. À época, Salles ficou insatisfeito com a montagem e abandonou o projeto sem finalizá-lo. Treze anos depois, revisitou o material e repensou todo o processo, debruçando-se especialmente sobre a maneira pela qual tratou o mordomo e sobre a confusão entre os papéis de patrão/documentarista e personagem/empregado. Lançou, em 2007, Santiago uma reflexão sobre o material bruto.

Santiago é, portanto, um filme em dois tempos. A montagem parte de uma visão perspectivada do presente para perscrutar o passado. As imagens de treze anos atrás são questionadas, examinadas, analisadas em si e em seus bastidores, já que tempos mortos, silêncios, instruções, equívocos e repetições do primeiro são dados a conhecer nesse segundo filme. Salles pretende revelar aquilo que permaneceria oculto, 
escondido do juízo do espectador, que teria acesso só ao "produto bem-acabado", com arestas aparadas. Os fios invisíveis da direção de atores, que o espectador comum muitas vezes considera como inexistente no documentário, são trazidos à baila por essa decisão. Na narração: "Minha mãe dizia: 'Santiago faz os mais lindos arranjos de flor que conheço'. Hoje já não sei por que, mas pedi a Santiago que me falasse de flores de pé e olhando para a parede". Ao personagem real foram solicitados uma postura corporal, um discurso, um olhar. Em outro momento: "Fica nessa posição, pensa um pouco na sua avó, na minha mãe... agora volta àquela posição”. Mais uma solicitação muito direta, dessa vez incluindo um pedido de interiorização, como se a introspecção e a lembrança da mãe e da avó facilitassem a chegada de um sentimento esperado para aquela cena, efeito de uma técnica de interpretação ficcional.

Na revisão do material bruto, ficam nítidos as escolhas calculadas e o forte controle do diretor sobre a atuação do retratado, deixando pouca margem à espontânea expressão do personagem. Não houve espaço para descobertas, para um encontro real e aberto com o ex-mordomo. Na confluência entre relações de classe e relações de cinema, o narrar a si mesmo orientado, dirigido, enquadrado, tolhido e interrompido pode ter privado o ex-empregado do gesto de revelar-se para lançar luz sobre um recorte delimitado pelo ex-patrão; manifesta-se para a câmera quase que somente aquilo que este já conhecia e considerava interessante. Subsiste uma sensação de que as imagens não renderam em 1992 porque João Salles considerou que o personagem não seria suficiente pra sustentar um filme. Em sua visão, foi preciso que o filme fosse também sobre si mesmo (João) e sobre o próprio cinema para que se garantisse o interesse e se justificasse um documentário. A obra, afinal, recebeu o subtítulo de uma reflexão sobre o material bruto - não uma reflexão sobre a pessoa.

Logo no princípio, o narrador diz: "Santiago morreu poucos anos depois dessa filmagem. Dele restaram 30 mil páginas e 9 horas de material filmado, além de minha memória e da memória de meus irmãos". Essa é uma narração feita no presente, tempo que é apresentado como se toda a negligência e o menosprezo que pesaram sobre Santiago tivessem sido superados. Contudo, a formulação sugere a existência de Santiago em função da família Moreira Salles, como se sua vida pudesse ser apreendida quantitativamente, em páginas, horas e nas memórias dos contratantes. Santiago não teria restado também na memória de outras pessoas? Não teria deixado outras marcas que o diretor nem cogitou procurar?

As bordas do filme de 1992, os fragmentos que seriam dispensados na montagem, transmutam-se no mote do filme de 2007. Acontece uma espécie de inversão em que a atenção de João Salles se volta agora para os bastidores, para o fora 
de quadro, deixando o próprio personagem e suas histórias, antes centrais, quase que relegados à margem; o centro vira margem, a margem vira o centro. Não deixa de ser uma contradição na qual, para atribuir a devida importância a Santiago, seja preciso tirar um pouco da importância de Santiago. Essa acaba sendo a contrapartida para que se possa desvelar um engano, expor uma injustiça, fazer uma retratação.

Um dos restos da imagem, que não é tematizado diretamente por João Salles, mas que se mantém nos dois filmes, é a melancolia de Santiago. Por duas vezes o ex-mordomo diz, ao comentar momentos de grande satisfação pessoal, que não poderia afirmar que estava feliz, "pero muy contento". Suas expressões faciais, sua solidão, o segredo que guardava, tudo isso nos leva a pensar em sua infelicidade, que não foi investigada pelo cineasta na filmagem (mas parcialmente na montagem, quando ele se detém sobre os poemas, por exemplo).

Noutra cena, Santiago relata que foi chamado a um brinde pelo seu aniversário, em meio a uma festa dos patrões: "isso foi para mim o prêmio mais grande. Festejei meu aniversário com champanhe francês", sendo que estava ali trabalhando durante suas férias, convocado pela patroa, numa festa alheia. Santiago demonstra um enorme orgulho ao ser cumprimentado por pessoas importantes, frequentadores da mansão dos Moreira Salles. Por mais que expresse contentamento, fica claro ali o caráter de exceção desses "pequenos reconhecimentos", o que revela o tamanho da desigualdade.

Santiago tinha certo fascínio pela nobreza. Apreciava a cultura erudita, as belas artes, a cerimônia, o luxo e a pompa. Escreve páginas infindáveis narrando a história da aristocracia universal, focando-se na biografia de reis, príncipes, marqueses e condes. Mas mesmo em suas fantasias e delírios de grandeza, ainda se vê como empregado - de gente rica, mas empregado. Tem todo um interesse pelos serviçais de outrora, aqueles que serviram às grandes figuras e personalidades. Foi criado pela avó, que havia sido "dama de companhia de uma marquesa piemontesa", revelando uma linhagem que o precedeu, explicitando as permanências históricas da divisão entre senhores e criados.

Próximo ao fim do filme, João apresenta uma reflexão crucial que provoca o espectador a reler o filme sob outra chave. Diz o narrador, em primeira pessoa:

Essa é a última filmagem que fiz com Santiago. Ela me permite fazer uma observação final. Não existem planos fechados nesse filme, nenhum close de rosto. Ele está sempre distante. Penso que a distância não aconteceu por acaso. Ao longo da edição, entendi o que agora parece evidente. A maneira como conduzi as entrevistas me afastou dele. Desde o início, havia uma ambiguidade insuperável entre nós que explica 
o desconforto de Santiago. É que ele não era apenas meu personagem; eu não era apenas um documentarista. Durante os cinco dias de filmagem, eu nunca deixei de ser o filho do dono da casa e ele nunca deixou de ser o nosso mordomo. (SANTIAGO, 2007)

Essa reflexão é adiada pelo filme, atrasada para os últimos momentos como que para coroá-lo. Há, nela, um teor de insight, de revelação final a descoberta de algo que tem o poder da explicação retroativa. Salles condensa um pensamento sobre as relações de poder extrafílmicas e a maneira como atravessam a linguagem cinematográfica, modulando enquadramentos, por exemplo. Podemos perceber que as composições que envolvem Santiago de fato o colocam à distância, sempre com diversos objetos como obstáculos entre ele e a câmera (Figura 2). Somado ao fato de que o filme é em preto e branco, tem-se a impressão de que Santiago está como que camuflado dentre os demais objetos, quase como se se misturasse ao cenário. Instigante também é a escolha da cozinha como espaço principal do filme. Se fosse na casa dos patrões isso faria mais sentido, mas dentro de sua própria casa? Distâncias sociais, distâncias do cinema.

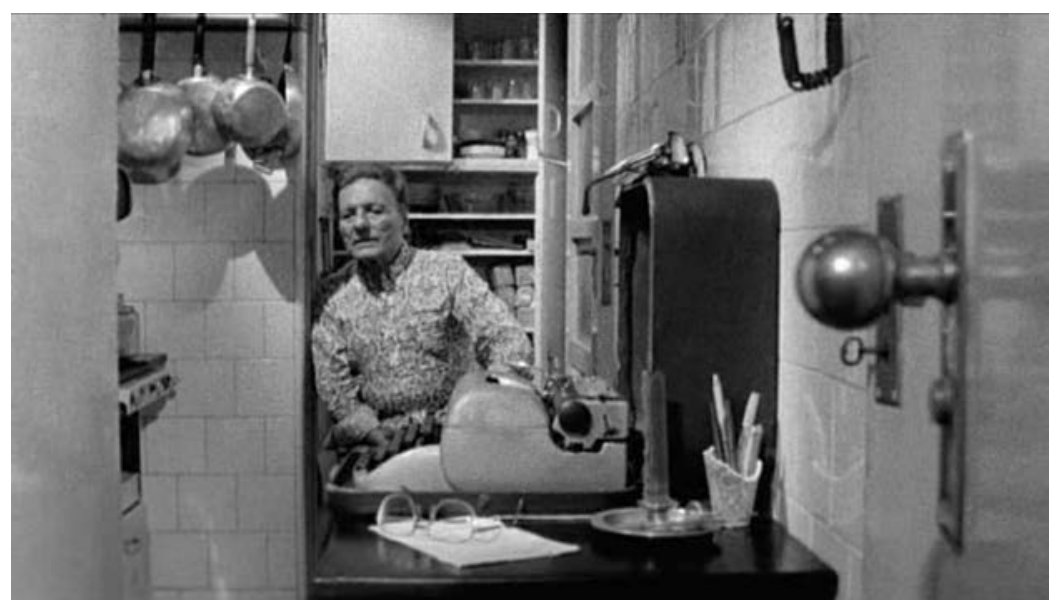

Figura 2: Fotograma de Santiago.

\section{Os antepassados}

A rede que conecta Babás a Santiago vem de longe. Quiçá tenha começado com os operários filmados pelos patrões Lumière, no que é considerado o primeiro filme projetado na história do cinema - A saída dos operários da fábrica funciona, 
aqui, como uma referência quase arquetípica. Imaginamos que os três fazem parte de uma constelação de filmes, que atravessam épocas e países, em que patrões filmam empregados, apresentando imagens cindidas por relações de poder ${ }^{4}$.

A saída dos operários da fábrica (1895) foi filmado em três versões, com diferenciação nas vestimentas e no fechamento dos portões, que não se completa em algumas delas. Por conta dessa repetição de planos, da coreografia dos personagens que saem harmoniosamente para a direita e para a esquerda, e também pelos poucos olhares para a câmera, entendemos que se trata de uma ação ensaiada, até certo ponto dirigida. Houve a tentativa de que a ação fosse completada (tivesse início, meio e fim, arrematada pelo fechamento dos portões) dentro da duração do plano, isto é, provavelmente os operários foram instruídos a se apressarem. O que entendemos por fora de quadro é emblematizado pelas operárias da fábrica Lumière que precisam correr para "caber" em um só rolo de película.

Em Operários saindo da fábrica (1995), Harun Farocki examina um conjunto de imagens de arquivo, de diversas origens, que trazem imagens de trabalhadores deixando a indústria. Na narração, sua voz perscruta esse motivo visual tão repetido na iconografia. Sobre as imagens dos Lumière, Farocki comenta: "Desta primeira projeção, fica na memória a pressa dos trabalhadores à saída, como se algo os puxasse. Ninguém fica no recinto da fábrica”. Logo o documentarista avança para três outros contextos de imagens, dizendo:

1975 em Emden, à saída da Volkswagen. Os trabalhadores correm como se algo os puxasse dali para fora.

1926 em Detroit: trabalhadores correm como se já tivessem perdido muito tempo.

De novo em Lyon, 1957. Correm como se soubessem onde tudo é melhor. (ARBEITER..., 1995)

A velocidade pode ser entendida em dois sentidos: seja a infligida pelo patrão em busca de uma maior produtividade em menos tempo, seja a que vem do próprio operário, ansioso pela liberdade e pela compensação do tempo perdido dedicado à geração de uma riqueza que não será sua. Terminadas as longas horas de trabalho, é preciso correr para aproveitar o curto tempo próprio.

\footnotetext{
${ }^{4}$ No Intenso Agora (2017), filme mais recente de João Moreira Salles, poderia se juntar a essa constelação. O documentário retoma e tematiza o curta dos Lumière, antes apenas um fantasma em Santiago. Além disso, começa com uma discussão sobre a imagem de arquivo de uma babá.
} 
Um século depois dos Lumière, a pressa é também um ponto recorrente na filmagem do mordomo Santiago. João Salles e sua equipe, nos idos de 1992, constantemente apressavam o personagem, faziam-no contar suas histórias e memórias com velocidade, quando não era interrompido sem cerimônia alguma. Em uma cena, Santiago precisa recitar uma oração em latim em disparada, por força do tempo corrido da equipe e da economia da filmagem, posto que rodavam em película, um material caro. Em outra, recebe a seguinte instrução de João Salles: "Fala aquela história dos quadros, que você fechava os olhos e o Monet virava Piero della Francesca... mas conta isso rápido pra gente". Mais adiante, quando, em meio ao seu discurso, Santiago faz uma menção a João - "Joãozinho, maravilhoso, João Moreira Salles" -, o diretor o interrompe e diz, retificando: "Fala de novo sem citar meu nome, vai! Vai lá. Conta a história logo que a gente tá com um pouco de pressa. Não, pode ir, vai!”. Santiago conta com tanta velocidade que quase tropeça nas palavras. Com certa frequência, escutamos as vozes dos dois sobrepostas, como se João não esperasse Santiago terminar de falar e desse ordens por cima de seus depoimentos, cortando e "corrigindo" sua fala enquanto ela transcorria, para conformá-la aos seus desígnios 5 .

Poderiam as interrupções e a pressão que o cineasta exerce pelo encurtamento dos tempos de fala dos personagens ser tributadas à especificidade do encontro entre diretores e personagens unidos por relações de trabalho prévias à realização do filme? O relacionamento, o trato entre as partes, seria diferente se não houvesse esse vínculo?

Tanto o espectador como o próprio personagem são levados a imaginar que o preço/duração da película ou a agenda do cineasta são mais importantes do que sua fala, ainda que seja o protagonista. Numa demonstração clássica do modo de operação do capitalismo - e que aqui se mescla com a operação do dispositivo cinematográfico -, o tempo do patrão vale mais do que o tempo do trabalhador.

Consta que a primeira versão de A saída da fábrica foi filmada em março. Das outras, para além da suposição do verão europeu, não se sabe a data. Pelas vestimentas dos operários, possivelmente mais formais do que as usadas no trabalho, supõe-se que eles foram chamados à fábrica (para não dizer "convidados" ou "convocados") em um dia de junho, no domingo depois da missa. Se foram remunerados por essa "atividade" ou mesmo se tiveram a escolha de não comparecer, apenas podemos especular. Na narração em tom livre e inventivo de Os primeiros

\footnotetext{
${ }^{5}$ Interrupções e o menosprezo ao tempo do empregado são vistos também em Doméstica: em meio a uma entrevista delicada em que a empregada Dilma compartilha episódios dolorosos de sua vida pessoal e conjugal, o telefone toca e a garota Perla sai para atender, interrompendo o momento e deixando a entrevistada solitária a esperar. Nesse filme, no entanto, a interrupção é feita por adolescentes, sujeitos menos conscientes da postura esperada de um documentarista profissional em situação de entrevista.
} 
filmes dos irmãos Lumière (1996), o historiador e cineasta Bertrand Tavernier comenta sobre as imagens: "Lumière coloca sua câmera em frente à sua fábrica e pede, implora, ordena que seus empregados saiam" (ressaltamos a repetição tripla do pronome possessivo: sua câmera, sua fábrica, seus empregados).

Em Santiago e Babás (mas também em Doméstica), temos relações de classe não mais num ambiente fabril, mas doméstico - o que é mesmo sintomático de uma passagem histórica, do foco das relações de trabalho do contexto industrial para um pós-industrial. Mudam os cenários, no entanto permanece algo da indefinição dos limites e fronteiras nas relações de classe, uma apropriação da mais-valia pelo capitalista que extrapola o tempo e o espaço devido ao trabalho.

Tanto Saída dos operários quanto Santiago e Doméstica (e Babás, em partes) são realizados não exatamente pelo patrão, mas pelo filho do patrão, o "sinhozinho", o "herdeiro", uma figura emblemática. Ao personagem do "filho do dono", no imaginário popular, geralmente se atribui a pecha de caprichoso, aquele que nasce em berço de ouro, não trabalha e a quem os empregados devem obediência e satisfação das vontades. Ao mesmo tempo, pode ser uma figura simpática, por vezes criado mais pelos empregados do que pelos próprios pais e com quem os empregados tecem relações mais afetuosas e menos distantes do que com os senhores, os contratadores de fato.

Poderia advir daí um entendimento, por parte dos empregados, do próprio filme como capricho do filho do dono a que se deve ceder e obedecer. A questão da anuência do personagem, um tema importante do âmbito da ética do documentário, coloca-se em relevo. É bastante provável que os personagens/empregados não se sintam livres para negar a participação nos filmes, entendendo essa atividade como mais uma dentre suas atribuições por contrato, uma hora extra não remunerada. Seu corpo é do patrão, sua imagem não lhe pertence. Se o filme é um encargo, atuar é mais um trabalho. Em Doméstica, Gabriel Mascaro expõe na montagem o momento em que um dos adolescentes aborda a empregada Lucimar, pergunta se pode filmá-la, ao que a moça simplesmente responde que sim e assina o termo de cessão de imagem sem sequer ler, com as mãos ainda molhadas da louça.

Contudo, algumas brechas revelam possibilidades de resistência diante desse poder que soa inescapável: imagens dos personagens com expressões de enfado, cansaço ou constrangimento povoam esses filmes, assim como respostas esquivas ou silêncios, o que denuncia ao espectador uma condição de insatisfação ou contragosto. E resta ao espectador o mal-estar, quem sabe uma sensação inquietante de conivência, por ser o destinatário de um filme sobre um personagem que talvez não quisesse ser filmado, em primeiro lugar. É o caso, por exemplo, 
do empregado Sérgio ${ }^{6}$, em Doméstica, claramente incomodado com a filmagem, que parece sentir como invasão. Santiago diversas vezes expressa aborrecimento e tristeza diante das negativas às suas perguntas e sugestões, das ordens duras e dos cortes súbitos de João Salles. Há uma diferença significativa entre eles: no caso de Santiago, foi opção de Salles manter essas "resistências" na montagem - e é só por essa decisão que essa discussão é possível; no caso de Doméstica, é Mascaro quem as trabalha, à revelia dos patrões adolescentes. É uma instância de distanciamento que permite que o desagrado dos empregados seja visto e tematizado no filme acabado: no caso de João Salles, um tempo de maturação após as filmagens, no caso de Doméstica, a intervenção de Mascaro sobre as imagens filmadas pelos adolescentes. Caso contrário, tudo seria facilmente ocultado e não chegaria ao espectador. É a má consciência dos diretores que permite sua emersão.

São filmes marcados por uma grande contradição. De um lado, os empregados são alçados à condição de homenageados. Ainda que não seja intencional, de alguma maneira os operários da fábrica Lumière foram imortalizados pelo cinema. Santiago foi "embalsamado" (termo usado pelo próprio filme) por João Salles. Consuelo Lins promove retratos, antes raros, de mulheres tão ignoradas ao longo de séculos. Tem-se, portanto, a homenagem, o interesse, a reverência aos personagens, supostamente salvos pelo cinema - de uma injustiça social e do apagamento. No entanto, a despeito das intenções, são obras em que se prolonga uma situação de dominação, que repetem no cinema uma mise-en-scène social pautada pela relação de obediência, a designação de um corpo a um determinado espaço, um pedido de imobilidade, de uma pose, de um figurino. A posição de cineasta diante desses sujeitos filmados parece não ser tão diferente da de patrão, afinal.

Assim, tais filmes não são apenas sobre os operários da fábrica Lumière, sobre Santiago, sobre as sete domésticas ou sobre as babás. São documentos, registros de relações de poder, da submissão de seres por outros, de diferentes formas de exploração, de violências mascaradas. Nesse sentido, ver tantos pontos se repetindo nessa trajetória de mais de um século do cinema, desde o cinematógrafo dos Lumière até os filmesdispositivo em digital, ajuda a entrever a complexidade da questão e a entender um pouco mais as formas pelas quais o cinema é atravessado pelas relações de classe. Merece atenção o fato de que, em todos esses casos, mesmo com a câmera em mãos do polo que detém mais poder, os filmes possibilitam que se inscrevam assimetrias e hierarquias, às vezes até mesmo a despeito de sua tematização e de seu reconhecimento pelos participantes.

\footnotetext{
${ }^{6}$ Sérgio e Santiago representam uma exceção no Brasil: empregados domésticos do sexo masculino.
} 


\section{O outro de classe?}

Em Cineastas e imagens do povo, Jean-Claude Bernardet (2003) alude ao “outro de classe" para se referir ao tipo de alteridade tratada nos filmes dos anos 1960 que ali aborda. Proletários e camponeses constituíam “o outro” em relação a cineastas e público, que compartilhavam raízes nos estratos médios. Não um outro qualquer, portanto; a diferença de classe era o principal atravessamento em questão.

Para Bernardet (2003), a passagem para os filmes que visavam a classe média dificultava a constituição desse outro porque a ela pertenciam cineasta e público. Não havia mais a mesma distância, a mesma possibilidade de objetividade. "Esse voltar-se sobre si mesmo faz oscilar o filme entre a postura científica, que institui o outro, e a identificação. Olhar no espelho perturba o método" (BERNARDET, 2003, p. 60). Daí que, em momento bastante posterior, nos deparamos com Babás, Santiago e Doméstica, filmes que miram um outro de classe no âmbito doméstico. De alguma forma, também há ali algum espelho a perturbar o processo, pois esse outro vincula diretamente quem filma: ao registrar o empregado num filme que de alguma maneira aborda o trabalho, o patrão é inevitavelmente convocado, para não dizer sugado para dentro. Seu lugar acaba sendo também questionado e problematizado, abrindo-se um campo propício para a autorreflexão e a tomada de posição. Na conclusão de Cineastas e imagens do povo, cuja primeira publicação data de 1985, Bernardet fala dos desdobramentos do modelo sociológico, sua crise e a transição para outras formas. Surgem filmes que posicionam mais centralmente o intelectual, suas angústias e interrogações. A esse respeito, pontua:

Esse movimento apresenta dois efeitos, pois, por um lado, contribui para relativizar o discurso do documentarista e, por outro, o coloca em primeiro plano. Esse primeiro plano, que pode passar por vontade de narcisismo (......), é ao mesmo tempo a indicação dos limites desse discurso. Trabalhando sobre seu discurso, o documentarista coloca-se no palco, sob os refletores, em vez de puxar os barbantes nos bastidores, e por isso mesmo nos convida a perceber e a refletir sobre sua posição de classe. (BERNARDET, 2003, p. 219)

Claro que Bernardet não tinha em mente os filmes que aqui discutimos, mas é interessante ver como sua fala adquire o tom de uma predição, atento a alguns dos encaminhamentos que o cinema vinha paulatinamente tomando. Em meados dos anos 1970, passa-se de filmes mais expositivos, de linguagem mais formatada e rigorosa, para obras mais fragmentadas, ambíguas, reflexivas. Por outro lado, 
em sua opinião, alguns deles não tinham o caráter radical, o espírito de pesquisa e de busca que apresentavam os filmes de sua análise. Se os primeiros davam pouca voz ao outro, encaixando-o em um discurso já previamente estabelecido, os segundos tampouco garantiam seu aparecimento. A linguagem mais livre acabava por cair também numa fórmula, numa rotina que pouca coisa revelava. Em nenhum caso o outro tomava a palavra, que lhe era apenas emprestada. Embora surgissem filmes menos ancorados em um saber unívoco, menos centralizadores, com possibilidade de fazer aparecer um pluricentrismo, Bernardet nota, categórico: "Derrubaram o pedestal do documentarista. Faziam, portanto, surgir o outro? Respondo: não" (BERNARDET, 2003, p. 217).

Mas se trata de um "outro de classe" muito específico, este que depende financeiramente do cineasta. Como lidar com essa alteridade fílmica com quem às vezes se divide o teto? As prévias relações de trabalho doméstico muitas vezes dificultam a constituição dos sujeitos filmados como interlocutores de fato. Se entendemos o "outro" como par, é difícil aceitar sem incômodo a expressão "outro de classe" para esses casos. Cerceados em sua expressão, interrompidos, com frequência eles não chegam a se constituir como um outro dotado de fala, numa relação de reciprocidade. Não há o estabelecimento de igualdade nem paridade. Não há um diálogo em mesmo patamar.

Nos estudos sobre alteridade, seja no bojo da antropologia ou da comunicação, o outro aparece como aquele a partir do qual eu me defino, aquele de quem preciso para saber quem sou. O outro é um elemento constitutivo do eu, posto que identidade e alteridade são pares indissociáveis (FRANÇA, 2002; LANDOWSKI, 2002). Alteridade e identidade se forjam em conjunto. Não se trata de processo simples e harmonioso; a maneira como nos relacionamos com o outro não passa inteiramente pela consciência. Perpassam, aí, afetos ocultos, reações mistas entre assimilação e exclusão, identificações, projeções.

Como acolher o outro na imagem? Embora nem sempre pacíficas, as relações de alteridade são entendidas frequentemente como positivadas e edificantes, concebidas de maneira romantizada, como parte de um processo de paridade em que as duas pontas se beneficiam de uma troca recíproca. Nem sempre é o caso.

O próprio João Moreira Salles (2001), em texto à Folha de São Paulo anterior a Santiago, ao falar da delicada situação do documentarista brasileiro de "alguém favorecido filmando quem não é", entende que algum grau de culpa social acaba por se fazer ingrediente da relação: "o resultado é que, na maioria das vezes, o documentarista já parte para gostar, o que significa ser condescendente, 
ou para ter pena, o que é pior, porque transforma as pessoas em vítimas" e, ainda segundo o diretor, vítimas dificilmente são interlocutores. Uma grande disparidade na relação muitas vezes faz com que as figurações desse outro de classe sejam atravessadas por elementos diversos: má consciência, paternalismo, comiseração, autoritarismo, rispidez, negligência.

Em Pode o subalterno falar? (2010), Gayatri Spivak alerta para a cumplicidade do intelectual que julga poder falar pelo outro, mas que, afinal, reproduz estruturas de poder e opressão ao mantê-lo silenciado. Sem lhe ter sido oferecida uma posição de fala, um espaço de onde possa falar e no qual possa ser ouvido, o outro acaba sendo apenas objeto de conhecimento de um intelectual que deseja falar por ele. A posição da autora fica explícita no prefácio de Sandra Almeida (2010, p. 16) ao dizer que o processo de fala se caracteriza por uma transação entre falante e ouvinte e que Spivak conclui que "esse espaço dialógico de interação não se concretiza jamais para o sujeito sub alterno que, desinvestido de qualquer forma de agenciamento, de fato, não pode falar". "Fala", aqui, não deve ser tomada em sua literalidade, como mera vocalização, pois a questão que se coloca é da possibilidade real de interlocução, de alternância de escutas, de uma fala que vem por livre expressão e desejo, e não inteiramente submetida a uma demanda de outrem.

Este trabalho não é uma defesa do abandono da expressão "outro de classe”, que dispõe tanto de pertinência quanto potência analítica, mas um desejo de destacar suas nuances e tensioná-la, demonstrando como ela, a depender de como for balizada, às vezes não alcança a descrição do que se passa. O outro de classe nos filmes em que patrões filmam seus empregados domésticos é dotado de algumas singularidades, ora marcado por certo silenciamento, ora pelo prolongamento da relação de obediência. Animados por sentimentos de justiça, gratidão e reconhecimento mesclados a um pouco de narcisismo, mas também pela possibilidade de elaboração e reinvenção da linguagem documental, são filmes que têm sua força, o mérito de abordar questões pouco ditas e uma capacidade de sedução cinematográfica, mas que aqui são alvo de nossa desconfiança - suspeitos no que tange à real interlocução, à situação de paridade e à construção da verdadeira escuta.

\section{Referências}

ALMEIDA, S. “Apresentação”. In: SPIVAK, G. Pode o subalterno falar? Belo Horizonte: Editora UFMG, 2010. p. 7-21.

BARROS, C. Trocas, hierarquias e mediação: as dimensões culturais do consumo em um grupo de empregadas domésticas. 2007. Tese (Doutorado em Administração) Universidade Federal do Rio de Janeiro, Rio de Janeiro, 2007. 
BERNARDET, J. C. Cineastas e imagens do povo. São Paulo: Companhia das Letras, 2003.

BERNARDET, J. C. Brasil em tempo de cinema: ensaio sobre o cinema brasileiro de 1958 a 1966. São Paulo: Companhia das Letras, 2007.

COMOLLI, J. L. Ver e poder: a inocência perdida: cinema, televisão, ficção, documentário. Belo Horizonte: Editora UFMG, 2008.

COMOLLI, J. L. "O desvio pelo direto". In: FESTIVAL DO FILME DOCUMENTÁRIO E ETNOGRÁFICO, 14, 2010, Belo Horizonte. Catálogo [...]. Belo Horizonte: Associação Filmes de Quintal, 2010. p. 294-317.

EDUARDO, C. "Santiago, de João Moreira Sales (Brasil, 2007): subjetividade mediada: entre a classe social e a família universal”. Cinética, [s. l.], 2007. Disponível em: https://bit.ly/2yxZ9Sb. Acesso em: 2 set. 2012.

FELDMAN, I. “Discurso sobre o método: aproximações entre os ensaios Santiago e Jogo de Cena”. In: ENCONTRO DA COMPÓS, 18. 2009, Belo Horizonte. Anais [...]. Belo Horizonte: PUC-MG, 2009. p. 1-13.

FELDMAN, I. "Um filme de: dinâmicas de inclusão do olhar do outro". Devires, Belo Horizonte, v. 9, n. 1, p. 50-65, 2012.

FRANÇA, V. "Discurso de identidade, discurso de alteridade: a fala do outro". In: GUIMARÃES, C. et al (org.). Imagens do Brasil: modos de ver, modos de conviver. Belo Horizonte: Autêntica, 2002. p. 27-43.

LANDOWSKI, E. Presenças do outro: ensaios de sociossemiótica. São Paulo: Perspectiva, 2002.

LINDEPERG, S. "Imagens de arquivos: imbricamento de olhares. Entrevista concedida a Jean-Louis Comolli”. In: FESTIVAL DO FILME E DOCUMETÁRIO ETNOGRÁFICO, 14., 2010, Belo Horizonte. Catálogo [...]. Belo Horizonte: Associação Filmes de Quintal, 2010. p. 318-345.

SALLES, J. M. "3 questões sobre o documentário". Folha de S. Paulo, São Paulo, 4 mar. 2001. Caderno Mais. Disponível em: https://bit.ly/3dQkt5u. Acesso em: 2 set. 2014.

SOUTO, M. Infiltrados e invasores: uma perspectiva comparada sobre relações de classe no cinema brasileiro. Salvador: EDUFBA, 2019.

SPIVAK, G. Pode o subalterno falar? Belo Horizonte: Editora UFMG, 2010. 


\section{Referências Audiovisuais}

ARBEITER Verlassen die Fabrik (A saída dos operários da fábrica), Harun Farocki, Alemanha, 1995.

BABÁS, Consuelo Lins, Brasil, 2010.

DOMÉSTICA, Gabriel Mascaro, Brasil, 2012.

LA SORTIE de l'usine Lumière à Lyon (A saída dos operários da fábrica Lumière), Louis Lumière, França, 1895.

SANTIAGO, João Moreira Sales, Brasil, 2007

submetido em: 8 ago. 2019 | aprovado em: $1^{\circ}$ abr. 2020 